\title{
ANALISIS KESESUAIAN HARAPAN MAHASISWA DENGAN PERSEPSI MANAJEMEN PADA PROGRAM STUDI MANAJEMEN DI DAERAH ISTIMEWA YOGYAKARTA
}

\author{
Kusuma Chandra Kirana \\ STIE Mira Indonesia \\ chandraw_19@yahoo.co.id
}

\begin{abstract}
The key success in winning the competition is the ability to achieve the objectives in creating and maintaining the customers. Therefore, the management of the program has to satisfy the customers. One way to obtain the customer satisfaction is to deliver a quality service required by the customers. It means that the management of the business schools need to have a good understanding on students need that there is no gap between the expectation of the students and the service they received. Thus, the understanding of their need is highly required the quality service can be provided. Based on the result of the study that the processed using servqual analysis instrument, the hierarchy and correlation ranking, there is a significant difference between consumers expectation in School of Management in Yogyakarta.
\end{abstract}

Keywords: expectation, perception, school of management program

\section{PENDAHULUAN}

Dunia pendidikan di Indonesia semakin berkembang pesat hingga dewasa ini, khususnya pada pendidikan tinggi. Selama ini, Yogyakarta sebagai kota pelajar, masih menjadi indikator mutu pendidikan, sehingga perkembangan dan pertumbuhan pendidikan di Yogyakarta masih menjadi tolok ukur bagi kotakota lainnya di Indonesia. Banyaknya pihak swasta yang menyelenggarakan organisasi pendidikan dan semakin tingginya tingkat kesadaran masyarakat akan pentingnya pendidikan, menyebabkan persaingan yang cukup ketat di antara para penyelenggara pendidikan. Ketatnya persaingan yang ada, jika tidak diikuti dengan standarisasi yang baik, akan membuat mutu menjadi tidak diperhatikan. Oleh karenanya pemerintah sejak beberapa tahun yang lalu, mendukung terbentuknya BAN-PT (Badan Akreditasi Nasional Pendidikan Tinggi). Adapun tugas dan fungsi BAN-PT fokus untuk meningkatkan kualitas penyelenggaraan Pendidikan Tinggi di Indonesia. 
Berdirinya BAN-PT dirasa memiliki dampak positif yang signifikan terhadap mutu pendidikan di Indonesia pada umumnya dan di Yogyakarta pada khususnya. Selama ini, minat masyarakat terhadap program studi manajemen, memang mengalami kenaikan meskipun tidak secara signifikan, hal ini dikarenakan makin beragamnya bidang ilmu yang tersedia, seperti kesehatan, teknologi komputer, teknologi animasi, dan sebagainya. Akan tetapi pertumbuhan program studi manajemen tetap ada. Sebagai salah satu disiplin ilmu, kurikulum program studi manajemen di Indonesia sudah cukup handal. Hal ini dibuktikan dengan semakin selektifnya lembaga pemerintah dalam memantau perkembangan kurikulum pendidikan. Namun yang masih harus menjadi pemikiran adalah muatan kurikulum praktikum yang menjadi mata kuliah dasar keahlian, karena kurikulum nasional yang ada, masih sarat dengan teori-teori yang tentu saja tidak sama dengan bisnis praktis.

Sekolah manajemen merupakan salah satu pendidikan formal paling menjanjikan hingga saat ini. Dari tahun ke tahun peminat pasar sekolah manajemen semakin meningkat. Berdasarkan data yang berhasil dihimpun peningkatan minat terhadap sekolah bidang manajemen di daerah Istimewa Yogyakarta tampak pada Tabel 1.

Tabel 1. Perkembangan Jumlah Mahasiswa Baru Sekolah Manajemen di Yogyakarta Tahun 2010-2013

\begin{tabular}{cccc}
\hline Tahun & Universitas & Sekolah Tinggi & Akademi \\
\hline 2010 & 4308 & 1723 & 1150 \\
2011 & 4751 & 1901 & 1266 \\
2012 & 4795 & 1918 & 1279 \\
2013 & 4873 & 1950 & 1300 \\
Total & 18.727 & 11.116 & 4995 \\
\hline
\end{tabular}

Sumber : Kopertis Wil. V DIY \& Ditjen Dikti, diolah

Berdasar Tabel 1 diketahui bahwa minat masyarakat terhadap sekolah manajemen mengalami kenaikan. Pertumbuhan minat masyarakat akan program manajemen disambut baik oleh pihak penyelenggara pendidikan tinggi. Pertumbuhan jumlah peminat manajemen yang diikuti oleh tumbuhnya jumlah sekolah dengan program dimaksud, memberi banyak pilihan bagi peminat pendidikan. Bagi para calon mahasiswa yang akan menjadi konsumen program, menjadi semakin selektif dalam menentukan pilihannya. Sekolah seperti apa yang sekiranya dapat memberikan kepuasan seperti yang mereka harapkan.

Dari sudut pandang pengelola program kunci sukses dalam memenangkan persaingan terletak pada kemampuan mencapai tujuan untuk menciptakan dan mempertahankan pelanggan. Tujuan tersebut dapat dicapai apabila pihak 
penyelenggara dapat memberikan pelayanan yang memuaskan dan memiliki keunggulan bersaing. Salah satu faktor yang perlu diperhatikan dalam mencapai hal tersebut adalah pemberian pelayanan yang berkualitas. Untuk itu pihak pengelola seharusnya dapat memahami secara serius apa yang menjadi harapan konsumennya. Pemahaman terhadap harapan konsumen diharapkan mampu menghindarkan terjadinya kesalahan persepsi.

Sejauh ini masih banyak terdapat ketidaksesuaian antara harapan konsumen akan kualitas layanan dan persepsi manajemen atas harapan tersebut. Hal ini terjadi karena kurangnya pemahaman pihak manajemen terhadap apa yang diinginkan oleh konsumennya. Akibatnya penyelenggara jasa pendidikan tidak mengetahui bagaimana suatu jasa seharusnya didesain, sehingga menimbulkan gap yang mempengaruhi turunnya nilai kualitas layanan di mata konsumen. Oleh karena itu, pemahaman terhadap kebutuhan yang diharapkan konsumen sebuah progran studi manajemen amat diperlukan agar kualitas layanan mampu diberikan secara prima. Selain dari itu, para pengelola program studi manajemen juga harus mengetahui dengan jelas dimensi kualitas mana yang paling dominan pengaruhnya terhadap minat calon mahasiswa, sehingga perlu mendapat prioritas utama dalam menentukan strategi layanan agar mampu memenangkan pasar sasaran. Penelitian ini mengangkat gap pertama dari penelitian Parasuraman (1998), sebagai fokus utamanya.

\section{TINJAUAN PUSTAKA DAN HIPOTESIS}

Pengertian persepsi menurut Kotler (2010), merupakan proses seseorang menyeleksi, mengatur dan menginterpretasikan masukan-masukan informasi untuk dapat menciptakan gambaran keseluruhan yang berarti. Sementara itu Barelson (1994) menyatakan bahwa persepsi adalah proses bagaimana seseorang menyeleksi, mengatur, dan menginterpretasikan masukan-masukan informasi untuk menciptakan gambaran keseluruhan yang berarti. Pendapat lain tentang persepsi datang dari Pride (2002) yang menyebutkan bahwa persepsi adalah proses pemilihan, pengorganisasian, dan penginterpretasian masukan informasi untuk menghasilkan penilaian. Masukan yang diterima dapat berupa proses pendengaran, penglihatan, penciuman, atau sentuhan.

Fandy (2010) menyatakan terdapat empat aspek yang mempengaruhi persepsi konsumen, yaitu:

1. Kualitas teknis: kemampuan personil pelayanan dan desain sistem pelayanan.

2. Kualitas integratif: kemudahan bagian-bagian yang berbeda untuk melakukan kerja sama.

3. Kualitas fungsional: termasuk semua aspek cara pemrosesan pelayanan pada konsumen antara lain gaya, lingkungan, dan ketersediaan. 
4. Kualitas hasil: berkaitan dengan pertanyaan apakah hasil pelayanan yang sesungguhnya memenuhi standar kebutuhan atau ekspektasi konsumen.

Berdasarkan pendapat para ahli tersebut maka dapat ditarik sebuah kesimpulan mengenai pengertian persepsi bahwa kualitas nilai terhantar sangat dibentuk oleh komponen-komponen yang pada akhirnya membentuk persepsi pelanggan tentang kualitas jasa.

Pengertian tentang ekspektasi merupakan suatu keadaan tertentu dimana seseorang menetapkan keinginan akan sesuatu yang ingin diperolehnya. Jika standar tersebuttelah terpenuhi, dalam keadaan seperti itulah kepuasan diperoleh. Zeithaml, Parasuraman dan Berry (dalam Fandy Tjiptono) mengemukakan faktor-faktor yang memenuhi tingkat ekspektasi, sebagai berikut:

1. Enduring Services Intensifiers.

2. Personal Need.

3. Transitory Service Intensifiers.

4. Perceived Service Alternative.

5. Self-Perceived Service Role.

6. Situational Factor.

7. Explicit Service Promise.

8. Implicit Service Promise

9. Word-of Mouth.

10. Past Experience.

Zeithaml, (1993) pada hasil penelitiannya juga mengemukakan adanya dua tingkat ekspektasi pelanggan jasa yaitu:

1. Tingkat kerja minimal yang dapat diterima. Ini didasari oleh perkiraan tentang jasa apa yang mungkin akan diterima dan tergantung pada alternatif yang tersedia.

2. Tingkat kinerja dasar yang diharapkan diterima pelanggan, yang merupakan gabungan dari ekspektasi apa yang bisa dan harus diterima zona toleransi.

Daerah di antara kedua tingkat ekspektasi ini disebut dengan zona toleransi. Zona ini dapat mengembang dan menyusut, serta berbeda-beda untuk setiap individu, perusahaan, situasi, dan aspek-aspek jasa. Untuk lebih jelasnya dapat dilihat pada Gambar 1. 


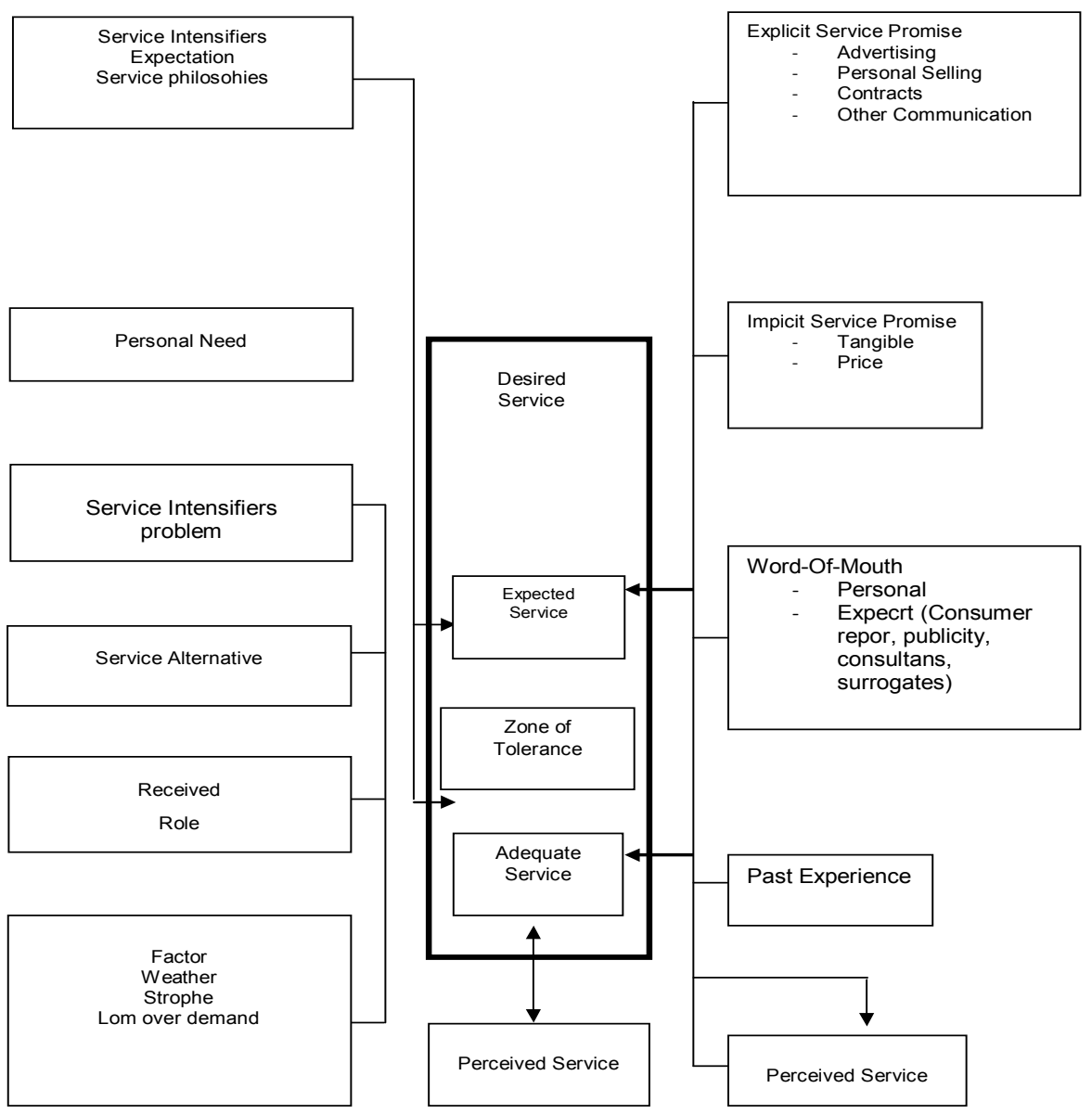

Sumber : Zeithaml, Parasuraman \& Berry 1993

Gambar 1. Model Konseptual Harapan Pelanggan terhadap Jasa

Kualitas produk, baik yang berupa barang maupun jasa, amatlah diperlukan. Kualitas didefinisikan sebagai kecocokan untuk pemakaian. Definisi ini menekankan orientasi pada pemenuhan harapan pelanggan. Pada dasarnya konsep kualitas bersifat relatif, tergantung pada perspektif yang digunakan untuk menentukan ciri-ciri dan spesifikasi. Terdapat tiga orientasi kualitas yang seharusnya konsisten antara satu dengan yang lainnya yaitu: persepsi konsumen, produk, dan proses. Dengan demikian konsistensi kualitas suatu jasa untuk menyumbang pada keberhasilan suatu perusahaan ditinjau dari kepuasan pelanggan, kepuasan karyawan, dan profitabilitas organisasi. 
Secara eksplisit, kualitas merupakan sarana untuk memuaskan tiga pihak dalam organisasi yakni pemilik mengharapkan keuntungan atas modal yang ditanamkan, pelanggan dengan kebutuhan dan keinginannya yang dapat terpenuhi, dan karyawan yang berkepentingan memperoleh kepuasan kerja baik secara moral maupun secara moneter. Dalam jangka panjang siklus ini akan berangkat dari orientasi pasar yaitu kepuasan pelanggan. Sementara itu dalam penilaian kualitas jasa, ahli pemasaran jasa Gronroos (2006) menyatakan kualitas total suatu jasa terdiri atas tiga komponen utama yaitu:

1. Technical Quality, yaitu komponen yang berkaitan dengan kualitas output jasa yang diterima pelanggan.

2. Functional Quality, yaitu komponen yang berkaitan dengan kualitas cara penyampaian suatu jasa.

3. Corporate Image, yaitu profil, reputasi, citra umum, dan daya tarik khusus suatu perusahaan.

Studi literatur mengenai persepsi, tingkat ekspektasi, dan faktor-faktor yang mempengaruhi tingkat ekspektasi serta dimensi kualitas pelayanan digambarkan hubungan antara dimensi kualitas, persepsi, dan tingkat ekspektasi bahwa pelanggan menetapkan tingkat ekapektasinya pada lima dimensi pelayanan, dipengaruhi 10 faktor. Kualitas dari lima dimensi pelayanan tersebut dinyatakan memuaskan apabila antara persepsi pelanggan tentang mutu dari lima dimensi pelayanan tersebut dapat memenuhi ekspektasi pada lima dimensi pelayanan. Mengenai hubungan antar variabel ini Zeithaml (1993) menyatakan, ada dua faktor utama yang mempengaruhi kualitas jasa yaitu expected service dan perceived service. Jika jasa yang diterima (perceived service) sama dengan yang diharapkan, kualitas jasa dipersepsikan baik atau memuaskan, dan sebaliknya. Kualitas jasa yang buruk bagi pelanggannya akan mengakibatkan ketidakpuasan yang ditunjukkan dengan adanya gap negatif.

Keunggulan suatu produk jasa tergantung pada keunikan serta kualitas yang diperlihatkan oleh jasa tersebut. Jasa secara spesifikasi harus bersifat marketing oriented serta memperhatikan kebutuhan dan keinginan pelanggan. Hal tersebut diperlukan karena jasa yang dirasakan dan dinikmati langsung oleh pelanggan akan segera mendapat penilaian sesuai atau tidak sesuai dengan ekspektasi dan keinginan pelanggan. Zeithaml, (1993) mengemukakan sebuah model dan menyusun beberapa acuan yang dapat dipakai sebagai pedoman dalam strategi penyesuaian langkah antara yang diharapkan pelanggan dan kinerja organisasi atau perusahaan. Terdapat lima kesenjangan (gap) yang menyebabkan penyajian atau penyampaian layanan tidak berhasil, yaitu:

1. Kesenjangan antara ekspektasi konsumen dan pandangan manajemen, di mana pihak manajemen tidak selalu dapat merasakan dengan tepat apa yang diinginkan atau bagaimana penilaian konsumen.

2. Kesenjangan antara pandangan manajemen dan spesifikasi mutu pelayanan, 
di mana pihak manajemen mungkin saja belum atau tidak menetapkan suatu standar kualitas yang jelas atau ada tetapi tidak realistis.

3. Kesenjangan antara mutu pelayanan dan sajian atau penyampaian pelayanan di mana banyak faktor yang mempengaruhi sajian pelayanan. Persoalan utamanya bisa disebabkan oleh kurang terlatihnya karyawan, atau beban kerja yang berlebih, kondisi mental yang buruk, dan rusaknya peralatan.

4. Kesenjangan antara penyajian pelayanan dan komunikasi eksternal. Ekspektasi pelanggan dipengaruhi oleh janji yang diberikan oleh pihak organisasi melalui iklan, tetapi kenyataannya lain.

5. Kesenjangan antara jasa yang dirasakan dan yang diharapkan. Terjadi bilamana pelanggan mengukur kinerja perusahaan dengan cara yang berbeda dan memiliki persepsi yang keliru mengenai kualitas jasa.

Model teori kualitas jasa dari Zeithaml (1993), dilihat pada Gambar 2.

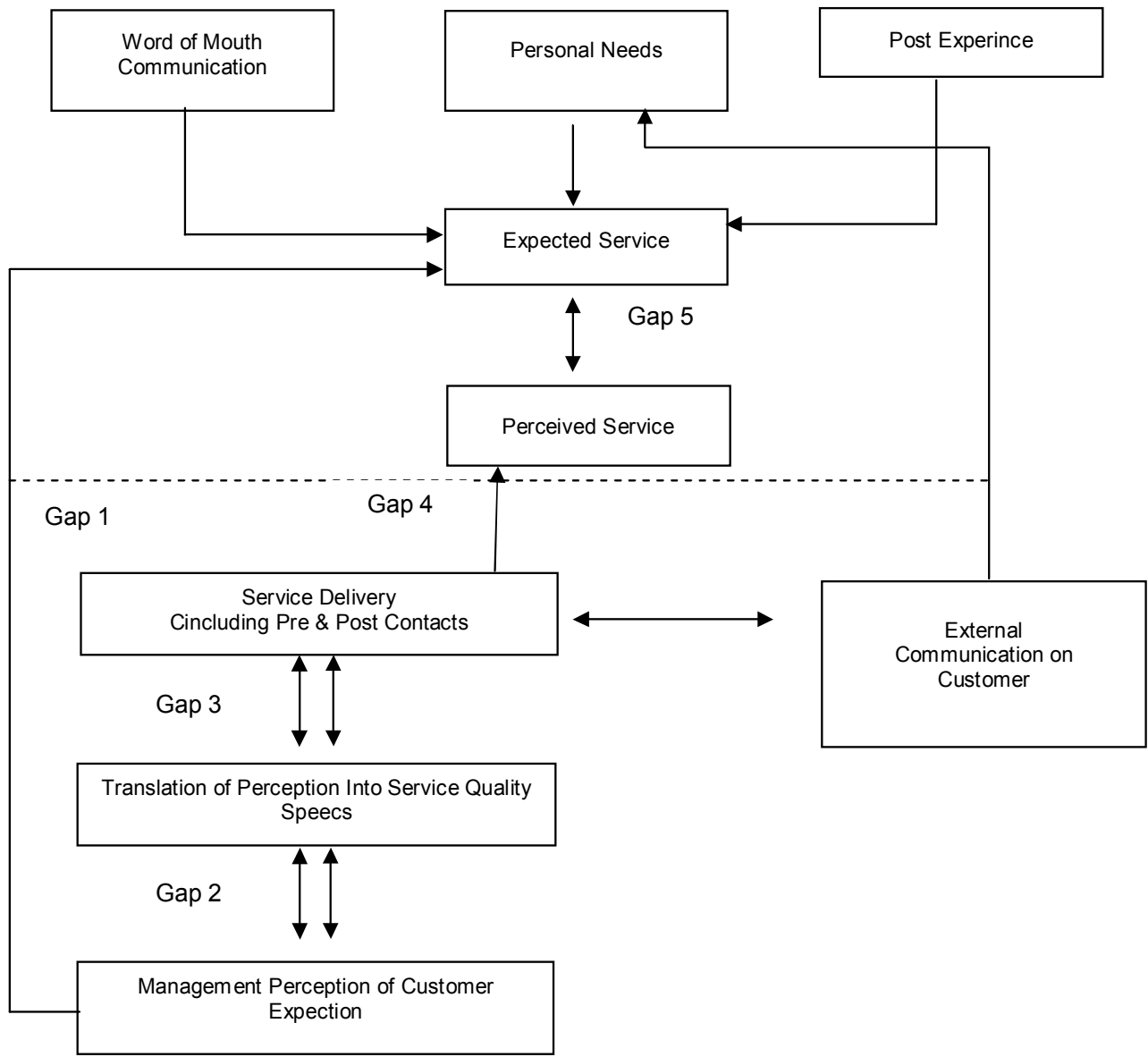

Sumber : Zeithaml, Parasuraman dan Berry 1990

Gambar 2. Service Quality Model 
Berdasarkan kajian pustaka di atas, maka dalam penelitian ini disusun dua hipotesis utama yang selanjutnya diuji dengan menggunakan fakta-fakta empiris yang diperoleh di lapangan. Hipotesis yang dimaksud dalam penelitian ini adalah:

1. Harapan mahasiswa terhadap dimensi kualitas pelayanan berbeda dengan persepsi manajemen pada Program Studi Manajemen di Yogyakarta.

2. Prioritas harapan mahasiswa terhadap dimensi kualitas pelayanan pada Program Studi Manajemen berbeda dengan prioritas persepsi manajemen di Yogyakarta.

\section{METODOLOGI}

Penelitian ini merupakan penelitian kuantitatif dengan metode sampling. Sampel diambil dari populasi subyek penelitian yang ada. Sumber data yang digunakan dalam penelitian ini adalah data primer yang merupakan data yang diambil langsung dari lapangan dan data sekunder yang sifatnya sebagai pelengkap. Penelitian ini menggunakan pendekatan deskriptif-evaluatif. Penelitian deskriptif tidak dimaksudkan untuk menguji hipotesis tertentu, tetapi hanya menggambarkan apa adanya tentang suatu variabel, gejala atau fenomena. Pendekatan evaluatif merupakan suatu proses yang dilakukan dalam rangka menentukan kebijakan dengan teknik mengembangkan kerangka berpikir dalam rangka mengambil keputusan. Hasil penelitian ini diharapkan dapat memberi masukan bagi para pengambil keputusan di bidang penyelenggaran Program Studi Manajemen.

Subjek penelitian ini terdiri atas dua komponen dalam setiap Perguruan Tinggi, yaitu para pimpinan dan mahasiswa. Untuk program peningkatan kualitas layanan, subjek penelitiannya adalah para pengelola program studi manajemen. Untuk mengetahui ekspektasi kualitas layanan, subjeknya adalah mahasiswa.

Pengambilan sampel menggunakan kombinasi stratified sample dan sampel random. Sampel random digunakan untuk menentukanprogram studi manajemen mana sajakah yang akan dijadikan sebagai sampel dalam penelitian ini. Dari teknik maka akan ditentukan sejumlah "n" sampel dari keseluruhan Perguruan Tinggi dengan Program Manajemen di Yogyakarta yang ada. Setelah ditentukan jumlah " $\mathrm{n}$ " sampelnya, maka data akan ditentukan secara acak (stratified random), sehingga semua mahasiswa pada Program Studi Manajemen yang dijadikan subjek penelitian mempunyai tingkat probabilitas yang sama untuk dijadikan sampel. Untuk menentukan besarnya rs, diunakan rumus:

$$
R s=1-\frac{6 \sum_{l=1}^{N} d i^{2}}{N 3-N}
$$


Untuk mewakili tiga kualifikasi pendidikan yang berbeda, yaitu D3, S1, dan S2. Teknik pengambilan data dilakukan dengan melalui kuesioner, wawancara, dan dokumentasi. Selanjutnya data dianalisis menggunakan SPSS 15,00 for Windows. Penelitian dilakukan di Daerah Istimewa Yogyakarta, selama kurun waktu 4 bulan, dimulai bulan Februari sampai dengan Juni 2013.

\section{HASIL PENELITIAN DAN PEMBAHASAN}

\section{Hasil Analisis Serqual secara Komprehensif}

Penelitian ini bertujuan untuk mengetahui tingkat harapan konsumen dan persepsi manajemen terhadap harapan konsumen tentang dimensi kualitas pelayanan program studi manajemen pada Perguruan Tinggi di Yogyakarta. Perhitungan data menggunakan alat bantu software berupa program worksheet for window. Hasil dapat dilihat pada Tabel 2.

Tabel 2. Hasil Perhitungan Servqual Prodi Manajemen Perguruan Tinggi DIY

\begin{tabular}{lccccc}
\hline \multicolumn{1}{c}{ Dimensi } & $\begin{array}{c}\text { Harapan } \\
\text { Konsumen }\end{array}$ & $\begin{array}{c}\text { Persepsi } \\
\text { Manajemen }\end{array}$ & Gap & $\begin{array}{c}\text { Ket } \\
\mathrm{P}>=<\mathrm{H}\end{array}$ & Signifikansi \\
\hline Tangible & 6,225 & 4,972 & 1,253 & $\mathrm{P}<\mathrm{H}$ & Signifikan \\
Reliability & 6,52 & 6,7056 & $-0,186$ & $\mathrm{P}>\mathrm{H}$ & Tdk Signifikan \\
Responsiveness & 6,45 & 6,791 & $-0,341$ & $\mathrm{P}>\mathrm{H}$ & Signifikan \\
Assurance & 6,4 & 6,5175 & $-0,118$ & $\mathrm{P}>\mathrm{H}$ & Signifikan \\
Empathy & 5,4 & 6,136 & $-0,74$ & $\mathrm{P}>\mathrm{H}$ & Signifikan \\
\hline
\end{tabular}

Sumber : Data Penelitian

Berdasarkan Tabel 2 dapat diketahui bahwa harapan mahasiswa pada Prodi Manajemen Perguruan Tinggi di DIY memiliki harapan yang tinggi pada dimensi reliability $(6,52)$, diikuti dengan responsiveness $(6,45)$, assurance $(6,4)$, tangible $(6,225)$, dan yang terakhir empathy $(5,4)$. Sementara itu persepsi manajemen, menangkap bahwa mahasiswa memiliki harapan tertinggi pada dimensi responsivness $(6,791)$, diikiti dengan dimensi reliability $(6,7056)$, assurance $(6,5175)$, empathy $(6,136)$, dan yang terakhir adalah dimensi tangible $(4,972)$. Artinya bahwa pihak pengelola Prodi Manajemen Perguruan Tinggi Di DIY mampu menangkap dengan baik mengenai harapan mahasiswanya.

Secara lebih rinci, Tabel 2 menyatakan bahwa mahasiswa memiliki harapan tinggi akan reliability, artinya para mahasiswa menganggap bahwa kemampuan pengelola dalam memberikan jasa sesuai dengan yang dijanjikan amatlah diharapkan oleh mahasiswa. Nilai harapan terendah para mahasiswa terdapat pada dimensi empathy, atau perhatian secara individual. Hal ini berarti para mahasiswa Prodi manajemen tidak terlalu memerlukan perhatian secara individual dari pihak manajemen. Bagi mereka kesesuaian janji lebih diharapkan. 
Sementara itu hasil analisis Serqual untuk persepsi manajemen mengenai dimensi kualitas, diketahui bahwa dimensi responsiveness memiliki nilai tertinggi. Artinya manajemen/pengelola Perguruan Tinggi menganggap bahwa dimensi responsiveness atau tanggung jawab, pemberian penjelasan terhadap pelayanan yang akan diberikan, usaha memberikan pelayanan yan tepat sesuai keinginan konsumen, serta waktu yang disediakan guna menyelesaikan persoalan yang dihadapi merupakan dimensi yang paling diprioritaskan mahasiswa. Nilai terendah pada persepsi manajemen terdapat pada dimensi tangible, yaitu penampilan secara fisik Perguruan Tinggi. Hal ini dapat diartikan bahwa selama ini pihak pengelola Prodi manajemen Perguruan Tinggi Di DIY menganggap bahwa tampilan fisik bangunan sekolah tidak begitu penting bagi mahasiswa.

Berdasarkan Tabel 2 dapat dilihat bahwa gap terbesar terjadi pada dimensi tangible $(1,253)$, di mana pengelola mempersepsikan begitu kecil atas harapan konsumennya. Hal ini berarti bahwa pihak pengelola Prodi Manajemen pada Perguruan Tinggi di Yogyakarta tidak mampu menangkap dengan baik apa yang diharapkan konsumennya.

\section{Hasil Analisis Proses Hirarki}

Analisis proses hirarki digunakan pada penelitian ini ditujukan untuk mengetahui dimensi kualitas yang paling diprioritaskan oleh mahasiswa selaku konsumen dalam memilih Prodi Manajemen, serta untuk melihat persepsi manajemen/pengelola atas prioritas tersebut. Perhitungan data menggunakan expert choice for windows. Hasil perhitungan proses hirarki, selengkapnya dapat dilihat pada Tabel 3.

Tabel 3. Hasil Perhitungan Proses Hirarki

\begin{tabular}{|l|c|c|}
\hline \multicolumn{1}{|c|}{ Dimensi } & Harapan Konsumen & Persepsi Manajemen \\
\hline Tangible & 0,137 & 0,115 \\
\hline Reliability & 0,242 & 0,217 \\
\hline Responsiveness & 0,242 & 0,364 \\
\hline Assurance & 0,242 & 0,223 \\
\hline Empathy & 0,137 & 0,081 \\
\hline Total & 1 & 1 \\
\hline
\end{tabular}

Sumber : Data Penelitian

Berdasarkan Tabel 3 diketahui bahwa mahasiswa memberi nilai cukup tinggi pada dimensi reliability, responsiveness dan assurance, lalu diikuti oleh tangible dan empathy mahasiswa Prodi manajemen pada Perguruan Tinggi di DIY selaku konsumen memiliki harapan yang tinggi akan reliability, responsiveness dan assurance. Ketiga dimensi tersebut memiliki skor nilai yang sama $(0,242)$. Hal ini diartikan bahwa mahasiswa menganggap penting kemampuan pengelola 
Perguruan Tinggi untuk memberikan jasa sesuai dengan yang dijanjikan dan keandalan kerja manajemen; tanggung jawab manajemen dalam merespon keluhan mahasiswa; dan kemampuan manajemen Perguruan Tinggi dalam memberikan rasa aman bagi mahasiswanya. Ketiga hal tersebut secara bersama-sama diprioritaskan. Nilai terendah terdapat pada dimensi tangible dan empathy $(0,137)$, yaitu dimensi tersedianya sarana pra sarana fisik serta dimensi perhatian personal pada mahasiswa.

Sementara pihak manajemen/pengelola memberikan nilai terlalu tinggi untuk dimensi responsiveness, diikuti dengan assurance, reliability, tangible dan memberi nilai cukup rendah pada empathy. Persepsi manajemen terhadap harapan mahasiswa atas dimensi kualitas yang diprioritaskan, tertinggi pada dimensi responsiveness $(0,364)$ yaitu tanggung jawab manajemen dalam memberikan respon terhadap keluhan mahasiswa. Sementara yang terendah ada pada dimensi empathy (0.081) yaitu kemampuan manajemen dalam memberikan perhatian personal.

Berdasarkan Tabel 3 dapat dilihat bahwa terdapat gap antara harapan mahasiswa dan persepsi manajemen atas harapan yang terbesar terdapat pada penilaian dimensi responsiveness $(0,122)$. Pada dimensi ini, pihak pengelola Perguruan Tinggi Prodi Manajemen di DIY mempersepsikan terlalu tinggi atas harapan mahasiswanya. Ini artinya pihak pengelola Perguruan Tinggi kurang dapat mempersepsikan dengan tepat apa yang menjadi harapan mahasiswanya.

\section{Hasil Analisis Korelasi Ranking}

Analisis korelasi ranking dalam penelitian ini digunakan untuk mengetahui hubungan antar ranking harapan mahasiswa selaku konsumen dan persepsi manajemen atas dimensi kualitas pelayanan Prodi Manajemen Perguruan Tinggi di DIY. Hasil perhitungan korelasi ranking selengkapnya dapat dilihat pada Tabel 4.

Tabel 4. Perhitungan Korelasi Ranking

\begin{tabular}{lcccc}
\hline \multicolumn{1}{c}{ Dimensi } & $\begin{array}{c}\text { Harapan } \\
\text { Konsumen }\end{array}$ & $\begin{array}{c}\text { Harapan } \\
\text { Konsumen }\end{array}$ & $\begin{array}{c}\text { Persepsi } \\
\text { Manajemen }\end{array}$ & $\begin{array}{c}\text { Persepsi } \\
\text { Manajemen }\end{array}$ \\
\hline Angka Proiritas & Ranking & Angka Prioritas & Ranking \\
Tangible & 0,137 & 4,5 & 0,115 & 4 \\
Reliabiliy & 0,242 & 2 & 0,217 & 3 \\
Responsiveness & 0,242 & 2 & 0,364 & 1 \\
Assurance & 0,242 & 2 & 0,223 & 2 \\
Empathy & 0,137 & 4,5 & 0,081 & 5 \\
\hline
\end{tabular}

Berdasarkan Tabel 4 diketahui bahwa ranking dari prioritas harapan mahasiswa mendekati ranking prioritas manajemen atas harapan mahasiswa. 
Artinya apa yang menjadi prioritas mahasiswa dengan prioritas persepsi manajemen meskipun mendekati namun tidak terdapat korelasi. Hal tersebut diperkuat dengan hasil perhitungan korelasi ranking dengan menggunakan rumus spearmen (rs) yang mengasilkan nilai 0,896 yang mana hasil ini lebih kecil dibandingkan dengan rs tabel 0,900 pada derajat sig 0.05 . Dengan demikian antara prioritas harapan mahasiswa dan prioritas persepsi manajemen terhadap harapan mahasiswa tidak saling berhubungan. Hal ini dapat saja terjadi sebab para mahasiswa pada Perguruan Tinggi Di DIY rata-rata menginginkan dimensi kualitas layanan secara bersama-sama atau dengan kata lain mahasiswa tidak memprioritaskan salah satu dimensi yang ada. Sehingga ada tidaknya kesesuaian antara prioritas harapan mahasiswa dan persepsi manajemen terhadap harapan mahasiswa tidak mempengaruhi mahasiswa dalam memilih Program studi Manajemen pada Perguruan Tinggi di DIY. Hal ini tidak terlepas dari citra Yogyakarta sebagai kota pelajar, dan sebagian besar mahasiswa adalah datang dari luar Yogyakarta. Citra Yogyakarta sebagai kota pelajar telah menjadi jaminan mutu bagi mereka untuk menentukan sekolah.

\section{Pembahasan}

Mengacu pada pendapat Kotler, (2010) bahwa kualitas hendaknya diawali dari kebutuhan konsumen dan diakhiri dengan persepsi konsumen. Artinya bahwa citra kualitas bukan berdasarkan sudut pandang penyedia jasa melainkan berdasarkan sudut pandang konsumen. Sebab konsumenlah yang merasakan jasa perusahaan, sehingga merekalah yang menentukan kualitas jasa.Berdasarkan konteks kualitas produk dan kepuasan, disepakati bahwa harapan pelanggan memiliki peranan yang besar sebagai standar perbandingan dalam evaluasi maupun kepuasan. Menurut Zeithaml (1993), harapan pelanggan merupakan keyakinan pelanggan sebelum mencoba atau membeli suatu produk, yang dijadikan standar/acuan dalam menilai kinerja produk tersebut. Berdasar pada pendapat tersebut, peneliti mencoba meneliti harapan mahasiswa selaku konsumen akan kualitas yang mereka inginkan, dengan cara meminta penilaian mereka atas jasa yang seharusnya diberikan menurut mereka dan memberikan urutan dimensi mana yang paling dipentingkan.

\section{Pembuktian Hipotesis}

Pengujian Hipotesis Pertama. Hipotesis pertama menduga harapan mahasiswa terhadap dimensi kualitas pelayanan berbeda dengan persepsi manajemen pada Program Studi Manajemen di Yogyakarta. Berdasarkan hasil perhitungan antara nilai $t$ hitung dan nilai kritis $t$ tabel adalah $t$ hitung $>t$ tabel pada derajat 0,1 , sehingga nilai t hitung berada di daerah penerimaan ha, (nilai t hitung 1,533 sementara t tabel 1,282). Hal tersebut berarti bahwa Ho yang menyatakan bahwa harapan mahasiswa terhadap dimensi kualitas pelayanan tidak berbeda dengan persepsi manajemen pada Program Studi Manajemen di Yogyakarta gagal diterima. 
Pengujian Hipotesis Kedua. Hipotesis kedua menduga prioritas harapan mahasiswa terhadap dimensi kualitas pelayanan pada Program Studi Manajemen berbeda dengan prioritas persepsi manajemen di Yogyakarta. Berdasarkan hasil perhitungan korelasi rangking diperoleh bahwa hubungan antara prioritas harapan mahasiswa dan prioritas persepsi manajemen terhadap dimensi kualitas pelayanan pada Program Studi Manajemen di Yogyakarta adalah $r s=0,896$. Tabel D menunjukkan nilai sebesar 0,896 adalah tidak signifikan pada $p<0,05$, yaitu 0,900 sehingga Ho yang menyatakan bahwa prioritas harapan mahasiswa terhadap dimensi kualitas pelayanan pada Program Studi Manajemen di Yogyakarta tidak berbeda dengan prioritas persepsi manajemen di terima.

Permasalahan penelitian yang pertama yang mempertanyakan bahwa apakah ada kesesuaian antara harapan mahasiswa dengan persepsi manajemen tentang harapan mahasiswa pada dimensi kualitas pelayanan pada Program Studi Manajemen di Perguruan Tinggi DIY telah terjawab. Pada Tabel 2 dapat dilihat bahwa gap yang timbul adalah disebabkan oleh tingginya nilai persepsi manajemen terhadap harapan mahasiswa (kecuali untuk dimensi tangible). Sehingga dapat dikatakan bahwa antara harapan konsumen dan persepsi manajemen terhadap mahasiswa atas dimensi kualitas pelayanan Perguruan Tinggi telah terdapat ketidaksesuaian yang positif. Ketidaksesuaian positif yang dimaksud adalah:

1. Dimensi reliability

Pada dimensi reliability terdapat ketidaksesuaian, di mana persepsi manajemen atas harapan mahasiswa lebih besar daripada harapan mahasiswa. Gap yang muncul sebesar 0,1856, artinya pihak manajemen Perguruan Tinggi mempersepsikan lebih tinggi atas apa yang diharapkan oleh mahasiswanya. Indikator yang digunakan dalam mengukur reliability dalam penelitian ini yaitu: pelaksanaan janji yang ditawarkan; kepedulian lembaga terhadap mahasiswa; program yang ditawarkan; dan ketepatan layanan sesuai yang dijanjikan serta keteraturan administrasi. Tingginya nilai persepsi atas harapan mahasiswanya, menunjukkan adanya keinginan yang kuat dari manajemen untuk mewujudkan keandalan kerjanya, namun hal ini bisa juga diartikan bahwa tingkat keandalan kerja manajemen ada belum optimal.

2. Dimensi Responsiveness

Terdapat ketidaksesuaian antara harapan mahasiswa dan persepsi manajemen akan harapan tersebut. Gap sebesar 0,341, di mana pihak manajemen memiliki persepsi lebih tinggi dari harapan mahasiswanya. Indikator yang digunakan dalam dimensi ini yaitu; pengetahuan sumber daya manusia mengenai visi/misi lembaga; keterampilan karyawan dalam memberikan pelayanan; ketanggapan karyawan dalam membantu keperluan mahasiswa; ketanggapan dosen terhadap mahasiswa; serta penyediaan 
waktu untuk konsultasi. Tingginya gap di sini menunjukkan keseriusan manajemen dalam upayanya untuk memberikan tanggung jawab.

3. Dimensi Assurance

Ketidaksesuaian menunjukkan angka gap sebesar 0.1175 , di mana persepsi manajemen lebih tinggi dari harapan mahasiswa. Artinya pihak manajemen Perguruan Tinggi di DIY menangkap harapan mahasiswa melebihi dari apa yang diharapkan. Indikator yang digunakan pada dimensi ini yaitu:kemampuan sumber daya manusia dalam memberikan rasa percaya diri kepada mahasiswa; jaminan rasa aman; sumber daya manusia yang konsisten; dan kemampuan sumber daya manusia dalam menjawab setiap pertanyaan pelanggan. Tingginya nilai persepsi manajemen atas harapan mahasiswa, menunjukkan adanya keinginan yang kuat dari pihak manajemen Perguruan Tinggi di DIY untuk memberikan jaminan atas program yang ditawarkan. Hal ini dapat dimaklumi, mengingat tingkat persaingan yang ketat di wilayah DIY. Selain itu, perubahan paradigma masyarakat yang menganggap bahwa sekolah tidak sekedar memperoleh gelar, namun juga ijin dan legalitas harus jelas, sehingga mampu memberikan jaminan proses pendidikan sampai selesai.

4. Dimensi Empathy

Sama dengan dimensi sebelumnya, pada dimensi empathy juga terdapat ketidaksesuaian yang lebih tinggi. Nilai gap yang muncul pada dimensi ini sebesar 0.736 . Indikatornya adalah: layanan prima; pilihan jadwal; perhatian karyawan terhadap individu; kesan yang ditimbulkan; dan karyawan terhadap kebutuhan spesifik pelanggan. Tingginya nilai gap terjadi karena keinginan yang kuat dari pihak manajemen untuk memperlakukan mahasiswanya dengan amat sopan, sekaligus merupakan betuk penghargaan yang tinggi pada masing-masing individu.

5. Dimensi Tangible

Pada dimensi tangible, ternyata pihak manajemen Perguruan Tinggi di DIY belum sepenuhnya mampu menangkap harapan mahasiswa. Hal ini ditunjukkan dengan rendahnya nilai persepsi manajemen terhadap harapan mahasiswa. Lebih rinci mengenai gap yang timbul pada dimensi tangible adalah: ketidaksesuaian terjadi karena harapan mahasiswa $(6,225)$ lebih besar dibandingkan dengan persepsi manajemen atas harapan tersebut $(4,972)$. Adapun gap yang muncul pada dimensi ini sebesar 1,253 artinya tidak semua pihak manajemen Perguruan Tinggi di DIY mampu memenuhi harapan mahasiswanya atas bentuk fisik yang meliputi bentuk bangunan; kelengkapan sarana dan prasarana; fasilitas dan kelengkapan perpustakaan; penampilan dosen; penampilan manajemen; dan penampilan karyawan. Tingginya nilai gap pada dimensi ini ternyata merupakan gap tertinggi dari empat gap yang ada. Akan tetapi yang perlu dicermati, gap yang muncul adalah gap positif, yaitu bahwa apa yang dipersepsikan oleh pihak 
manajemen masih lebih tinggi dibandingkan dengan yang diharapkan oleh mahasiswa.

Berdasarkan analisis pembahasan gap atas 5 dimensi kualitas layanan tersebut dapat dikatakan bahwa jawaban atas permasalahan pertama sudah terjawab, yaitu, terdapat ketidakseseuaian antara harapan mahasiswa dengan persepsi manajemen terhadap persepsi mahasiswa.

Permasalahan kedua, mengenai dimensi pelayanan manakah yang menjadi prioritas harapan mahasiswa dan yang dipersepsikan oleh manajemen ketika memilih Program Studi Manajemen pada Perguruan Tinggi di DIY dan yang dipersepsikan oleh manajemen juga telah terjawab. Berdasarkan Tabel 2 dapat diketahui bahwa terdapat perbedaan mengenai tinggi rendahnya nilai harapan mahasiswa dan persepsi manajemen atas dimensi kualitas pelayanan. Perbedaan yang dimaksud terjadi pada skor penilaian antar dimensi yaitu: pihak manajemen menganggap bahwa dimensi reliability, responsiveness dan assurance, memiliki nilai yang sama tinggi $(0,242)$. Dengan demikian ketiganya secara bersama-sama menjadi prioritas dalam memilih Perguruan Tinggi. Setelah ketiga dimensi tersebut, mahasiswa baru mengharapkan dimensi tangible dan emphaty yang keduanya memiliki skor nilai sama besar $(0,137)$. Sementara itu, pihak manajemen perguruan tinggi menangkap dimensi responsiveness adalah dimensi yang paling diprioritaskan oleh mahasiswa dalam memilih, dan penekanan ada pada ketanggapan manajemen dalam merespon keluhan mahasiswa. Hal ini dapat juga diartikan bahwa selama ini di DIY sudah terjalin komunikasi yang baik antara mahasiswa dan manajemen Perguruan Tinggi.

Secara lebih jelas jawaban atas permasalahan kedua adalah sebagai berikut:

1. Dimensi kualitas pelayanan yang menjadi prioritas harapan mahasiswa secara berurutan adalah reliability, responsiveness, dan assurance yang ketiganya secara bersama-sama menempati urutan teratas $(0,242)$ kemudian diikuti oleh dimensi tangible dan empathy $(0,137)$.

2. Dimensi kualitas pelayanan yang dipersepsikan manajemen menjadi prioritas harapan mahasiswa adalah dimensi responsiveness $(0,364)$, assurance $(0,223)$, reliability $(0,217)$, tangible $(0,115)$, dan empathy $(0,081)$. Jawaban atas permasalahan kedua sekaligus merupakan jawaban permasalahan ketiga yang mempertanyakan apakah persepsi manajemen tentang prioritas harapan mahasiswa ketika memilih Program Studi manajemen pada Perguruan Tinggi di DIY sesuai dengan prioritas harapan mahasiswanya. Berdasarkan Tabel 4 dapat diketahui bahwa meskipun terdapat ketidaksesuaian prioritas harapan mahasiswa dengan prioritas yang dipersepsikan oleh manajemen namun angka ranking kedua sampel tersebut saling berdekatan. Tabel 3 juga menunjukkan bahwa mahasiswa selaku konsumen menyatakan bahwa reliability, responsiveness dan assurance adalah tiga dimensi kualitas 
pelayanan yang paling diprioritaskan dalam memilih Perguruan Tinggi. Dengan demikian mahasiswa menganggap bahwa tiga dimensi kualitas tersebut amat penting diharapkan ada pada Perguruan Tinggi di DIY. Sementara itu, pihak manajemen menerjemahkan bahwa dimensi kualitas yang paling diprioritaskan oleh mahasiswa adalah responsiveness yang penekanannya ada pada ketanggapan manajemen dalam merespon keluhan konsumen.

Hasil lainnya dalam penelitian ini, juga dapat ditunjukkan pada Tabel 4 bahwa antara prioritas harapan mahasiswa dengan persepsi manajemen terhadap harapan mahasiswa memiliki korelasi dengan nilai koefisien korelasi sebesar 0,896 . Tingginya nilai responsiveness dari persepsi manajemen, merupakan perwujudan tingginya tingkat persaingan antar perguruan tinggi di DIY agar menarik mahasiswa.

Secara keseluruhan dapat dikatakan bahwa pihak manajemen Perguruan Tinggi di DIY hampir berhasil menangkap keinginan mahasiswanya, bahkan pada dimensi responsiveness konsumen merasa amat puas. Kepuasan yang dimaksud ditunjukkan dengan tingginya nilai persepsi manajemen dibandingkan dengan nilai harapan konsumennya serta berdasarkan pada hasil wawancara langsung dengan beberapa mahasiswa. Namun yang perlu digarisbawahi oleh para pengelola Perguruan Tinggi di DIY, bahwa tidak ada nilai kepuasan yang mutlak sehingga pihak pengelola/manajemen Perguruan Tinggi di DIY jangan terjebak ke arah inefisiensi.

\section{KESIMPULAN}

Kesimpulan yang dapat diambil dari hasil penelitian ini adalah:

1. Terdapat perbedaan yang signifikan antara harapan mahasiswa dan persepsi manajemen tentang harapan mahasiswa berdasarkan dimensi kualitas yang terdiri atas: tangible, reliability, responsiveness, assurance, dan empathy.

2. Prioritas dimensi kualitas layanan Program Studi Manajemen pada Perguruan Tinggi di DIY menurut harapan mahasiswa adalah: reliability $(0,242)$, responsiveness $(0,242)$, assurance $(0,242)$, empathy $(0,137)$, dan tangible $(0,137)$. Prioritas dimensi kualitas pelayanan Perguruan Tinggi di DIY menurut persepsi manajemen adalah: responsiveness $(0,364)$, assurance $(0,223)$, reliability $(0,217)$, tangible $(0,115)$, dan empathy $(0,081)$

3. Persepsi manajemen tentang prioritas harapan mahasiswa ketika memilih Program Studi Manajemen pada Perguruan Tinggi di DIY sesuai dengan prioritas harapan mahasiswanya.

\section{SARAN}

Berdasarkan kesimpulan yang ada dalam penelitian ini, peneliti memberikan beberapa saran sebagai berikut: 
1. Apapun kondisi Perguruan Tinggi di DIY saat ini, manajemen memiliki fundamental yang kuat untuk memberi pelayanan yang terbaik bagi mahasiswa. Ini perlu dipertahankan agar Perguruan Tinggi tidak ditinggalkan mahasiswanya. Selain itu, manajemen Perguruan Tinggi pelu lebih meningkatkan pelayanan dari sisi tampilan fisik, sebab ternyata mahasiswa mempunyai harapan yang tinggi atas dimensi ini.

2. Pihak pengelola Perguruan Tinggi hendaknya senantiasa melakukan perbaikan-perbaikan dalam upaya memahami prioritas harapan sesuai yang diinginkan mahasiswanya.

3. Manajemen masih harus menata sistem pengajaran dengan lebih baik dan baku agar tidak terjebak pada upaya pemenuhan kepuasan konsumen yang beragam, sebab semakin tinggi tingkat kepuasan konsumen yang hendak dicapai maka akan semakin tinggi pula nilai kepuasan yang dituntut, di mana ini akan berdampak pada tingginya biaya operasional.

4. Perlunya penelitian lanjutan mengenai gap atas dimensi kualitas layanan sehingga para pengelola Perguruan Tinggi dapat memberikan pelayanan yang sesuai.

5. Pihak manajemen perlu lebih meningkatkan kualitas pelayanan pada dimensi reliability, assurance dan empathy, karena dimensi ini merupakan dimensi yang menjadi prioritas harapan mahasiswa.

6. Pihak pengelola PerguruanTinggi di DIY perlu lebih memperhatikan harapan mahasiswa atas dimensi tangible sebab pada dimensi ini pihak manajemen belum mampu menangkap dengan baik apa yang menjadi harapan dari mahasiswanya.

\section{DAFTAR PUSTAKA}

Fandy Tjiptono (2010), Manajemen Jasa, Yogyakarta: Penerbit Andi.

Groonroos, Cristian (2006), Service Management and Marketing (Managing the Moments of Truth in Service Competition) New York: Maxwell Mc. Millan Int.

Kotler, Philip (2010), Marketing Managemet New Edition: Analysis, Planning, Implementation and Control, 9 th Ed. Englewood Clifts, N.J: PrenticeHall International, Inc.

Parasuraman A, Zeithaml and Berry (1998), A Multiple-item Scale for Measuring Consumer Perception of Service Quality. London: CMP.

Zeithaml, Valari A, Leonard L. Berry, and A. Parasuraman (1993), The nature and Determinants of Customer Expectations of Service. Journal of Academy of Marketing Science, vol. 21, No. 1, pp. 1-12. 
